\title{
Implications of Plant Selectors' Rights for herbage seed production
}

\section{a grower's viewpoint}

\section{G. B. ROBERTSON \\ R.D. 6, Ashburton}

ABSTRACT. Over $60 \%$ of the herbage seed produced in New Zealand is exported but because plant breeders have concentrated on the local market New Zealand seed has lost its pre-eminence in the United Kingdom. The introduction of Plani Selectors' Rights will encourage the New Zealand seed industry to meet market requirements. There is little future in multiplying overseas-owned cultivars in New Zealand. A progressive seed industry requires greater cooperation between breeders, farmers and merchants.

Key words: Plant Selectors' Rights, herbage seed production, New Zealand.

\section{INTRODUCTION}

In explaining my vicwpoint on Plant Selectors' Rights as a grower, I am going to look mainly at the export market. I do this because in recent years more than $60 \%$ of our herbagc seeds have been exported and even the price of seed marketed locally is by and large set by export sales.

Plant Breeders Rights have been around for a long time. Along with the autobahns of Germany they were one of the few useful legacies Adolph Hitler left Europe. Thus the European breeders have been operating for a long time under a system that encourages breeders to breed cultivars for 'specific markets, promote them well. market them properly, and reap the rewards.

We, on the other hand, have relied on producing seed of free cultivars, have done no promotion because there has been no agent to promote a specific cultivar, and, because the cultivars have been public, there has been no attempt to tailor production to suit market demand. Also we have made no real attempt to produce cultivars specifically for overseas markets. We have chosen to use our plant breeding resources solely to produce cultivars for New Zealand uses.

There are reasons used to justify this policy, the most persuasive being that money is better invested in raising the productivity of New Zealand pastoral farming through plant breeding for the local market than using our plant breeding resources in breeding for the export market.

While that may well be true, I would suggest that resources invested in breeding for export markets should be evaluated as an investment in its own right and not necessarily at the expense of breeding for New Zealand pastoral farming.

With Plant Breeders' Rights firmly established in at least some of our markets, we should be encouraged to devote some additional efforts to breeding for these markets.

\section{THE UNITED KINGDOM MARKET}

When grassland improvement got under way in the United Kingdom in the 1920s, a great deal of notice was taken of New Zealand's success in pasture management and in particular the work of Sir Bruce Levy. The British farmer began using New Zealand cultivars and as grassland improvement was promoted by extension officers they were also promoting the use of New Zealand seeds.

However, since the introduction of Plant Breeders' Rights, European breeders, and in particular the Dutch, saw the potential of the British market and bred and promoted cultivars specifically for that market.

At the same time, we in New Zealand neglected to promote our cultivars, did no breeding for that market, and so as a result of our thorough neglect of any marketing strategy and the European breeders' aggressive market oriented breeding and production, we lost our 
pre-eminence in the British market. We have now been reduced to supplying outdated cultivars that sell just because they are cheap.

Certainly, many of our cultivars are still on the national list in Britain, which means they are allowed on to the market, but to be commercially viable and that means attractive to farmers they must also be on the recommended list as published by the National Institute of Agricultural Botany. This is an independent assessment of their value to farmers and of the 43 cultivars on last year's recommended list for perennial (Lolium perenne L.) and Italian ( $L$. multiflorum Lam.) ryegrasses, we had only one entry - 'Grasslands Manawa' (L. multiflorum $X$ perrnne) - which had a partial recommendation for special uses.

As an indication of our opponents' grip on the market, of the 43 cultivars, 26 were Dutch, 4 were from Denmark, 4 from Belgium and 8 were British.

Thus we continue to sell in Britain because of cheapness or occasional shortfalls in proprietary cultivars. This year we are selling cur perennials at comparatively high prices (that is, high by our standards) because of a current shortage, but past events would suggest that within 12 months the boom will be over and we will be back to a lower price level.

\section{COSTS OF PRODUCTION}

There are people, both in New Zealand and in the seed trade overseas, who believe that we can produce seed very cheaply her:: because the seed crop is being taken as a by-product from a pasture used for grazing livestock. While there are certain production costs that are lower than for a European seed producer and very occasionally lower than in North America, I am sure that this conference has illustrated the high level of physical inputs and management skills that are needed to achieve good yields of high quality herbage seeds, Seed production is now a specialized business with the majority of seed being produced from crops grown specifically for harvest.

Our current cost structure in arable farming rules out the catch crop of seed which is inevitably a lower yielding crop, unless, paradoxically, that seed is going to fetch a very high price.

\section{QUALITY CULTIVARS}

There is another reason why we should beware of selling low quality cultivars cheaply within the EEC and that is because the EEC gets very upset by cheap produce entering the market (and this includes all agricultural produce), particularly if that produce is also low quality. They believe in high farm prices but they are also very conscious of quality. By sending quantities of outdated seed at low prices we are simply inviting a reaction in the form of import restrictions. This is starting to happen now with our seeds, particularly as a result of Danish and Dutch attempts to protect their market. For these reasons, we should be basing our export production on cultivars that are commercially attractive if we are to sustain a viable seed industry.

For example, as most of our perennial ryegrass is used as an amenity grass, we should have been giving some attention to the production of specialist amenity ryegrasses. At present there is an ever-increasing demand for perennial ryegrass for this purpose and the market is paying a very high premium for cultivars of fine-leaved dwarf perennial ryegrass. Certainly seed production is more difficult and yields lower for these cultivars, but the fact that they are fetching prices at least three times as high as 'Grasslands Ruanui' would indicate that this is a trade we should have been taking seriously.

Much of what 1 have said also applies to white clover (Trifolium repens L.). Over the last year, wholesale prices in the U.K. for cultivars that compete with 'Grasslands Huia' have been up to $\$ 6$ a kilogram, with our major competitor, Danish Milkanova, selling at $\$ 3.86$ a kilogram. Grasslands Huia was priced at $\$ 2.31$ a kilogram. This again is the result of an outdated cultivar being poorly marketed.

In the future there should be an expanding market around the world for white clover as a result of ever-increasing fertilizer nitrogen prices, and even in intensive grass production with high rates of artificial nitrogen there is interest in introducing clover to improve palatability and digestibility. We are now the major supplier of white clover in world trade, but this is based solely on one cultivar, Grasslands 
Huia, which sells on the grounds of availability rather than always being best for the job.

I should say here that when I speak of our cultivars being unsuited to many of our markets, I mean in terms of cultivar; in terms of physical quality, that is purity and germination, our seed is still highly regarded.

The lesson from all this is that when Plant Brecders' Rights are introduced marketing becomes more sophisticated and there is greater incentive to produce attractive cultivars. I hope we can learn from our experience in Europe as Plant Breeders' Rights are introduced to other countries to whom we presently sell seed.

I am encouraged by the enthusiastic manner in which the Crop Research Division is looking to the export potential of New Zealand cereal cultivars since the introduction of Rights. This is good for New Zealand agriculture but there would be even more to be gained as an industry in looking to the export of new proprietary cultivars of herbage seeds that are sought after by our customers.

In cereals, the breeders will receive royalties on cultivars that find a place overseas, but the multiplication of seed will be carried out, with a few possible exceptions in the country concerned, because the costs of shipping bear heavily on the selling price of cereal seed. But in herbage seeds we not only have the potential to establish our own cultivars alongside the top Dutch, Danish or American cultivars, but, because shipping costs are not such a major component in the price of higher valued herbage seeds, also have the opportunity as farmers to produce the seed here in New Zealand.

\section{MULTIPLICATION OF OVERSEAS CULTIVARS}

There are those who suggest that there is potential for us in the business of multiplying overseas-owned cultivars in New Zealand for re-export. I may be in the minority, but I doubt if there is much future in this for oul herbage seed industry. Merchants may bc enthusiastic about the potential but really, and especially from a farmer's point of view, we are held over a barrel. Let me quote an example.

Suppose a Dutch seed company wants to multiply in New Zealand a cultivar of perennial ryegrass that is selling well in. say. the
U.K. perhaps at prices up to $100 \%$ higher than we are getting there for our Ruanui. They need to offer a price to the New Zealand grower marginally above what the grower can make out of growing Ruanui and then, having had the seed produced comparatively cheaply in New Zealand, proceed to market it at a very high profit.

The Danish seed industry was doing a lot of multiplication for the Dutch seed companies in the past until they woke up and started breeding their own cultivars for export.

There is, however, one exception to my disenchantment with multiplication of overseas cultivars and that is multiplying British white clovers here. Plant breeders in the U.K. have bred some very good cultivars, particularly the large-leaved upright types that can survive and contribute to production under high levels of bag nitrogen. These cultivars are not being used because of the lack of available seed. The British climate is so unsuitable for white clover seed production that the trade has had to look elsewhere for multiplication.

A little is being multiplied in Denmark and some in North America but they would like us to produce seed in New Zealand and I am sure we cculd do a good job. However, to date our authorities have refused to allow this to happen because there would be contamination of thein cultivar by hard seeds of Grasslands Huia.

There are four points I would make:

(1) The multiplication of 'Grasslands Pitau' would indicate that other cultivars can in fact be multiplied besides Grasslands Huia.

(2) The Danes have a bigger problem with hard seeds in their white clover than we do, yet are able to change cultivars in a given paddock.

(3) We have not until very recently even started to look at ways of maintaining purity in the event of changing cultivars in a given area, and $I$ am sure if we really wanted to we could do it successfully.

(4) Because the British seed trade is very keen to see us multiply their clover, we could virtually dictate the price for doing the job. 


\section{CONCLUSION}

With the possible exception of white clover, we should be breeding for export and hopefully now that Plant Selectors' Rights are here we have part of the mechanism for introducing the necessary change. However, like any useful change, it will require a new approach. From the breeder, will be needed an awareness of markets outside New Zealand, and, while I do not wish to underestimate the problems or expense involved in breeding for markets other than New Zealand, I am sure it could be done.

Merchants will have to change from being merely traders to active marketers with all that that entails. I have no doubt that there are New Zealand companies who would do this very well if they were given exclusive rights to a cultivar with genuine market potential.

Farmer attitudes will have to change, too. Instead of assuming the right to grow any amount of seed of whatever cultivar we choose and then seeking to sell it on the open market, we will have to be prepared to grow these new cultivars on contract so that the agent can ensure the appropriate amount of seed to suit the market.
However. for this to happen we would want, as farmers, to have a more open commercial arrangement between the growers and seed companies. We would have no fixed price contracts, but "participation" contracts, whereby the final price to the grower depends on the sales of that cultivar - in many ways similar to "pooling" in the meat industry.

It is this co-ordination and co-operation that will have to be encouraged in order to adopt a sophisticated marketing strategy.

Any large maunfacturer has, as part of his business, departments dealing with research and development, manufacturing, and marketing. In marketing herbage seeds we need more co-ordination between research and development - the breeders: the factory w the farmers: and the marketing division - the merchants. We have to think as components of a New Zealand seed industry, not as individuals.

The introduction of Rights in New Zealand on its own will not solve our marketing problems. It must be part of an overall marketing strategy, that would secure a place in international markets for the New Zealand herbage seed industry. 